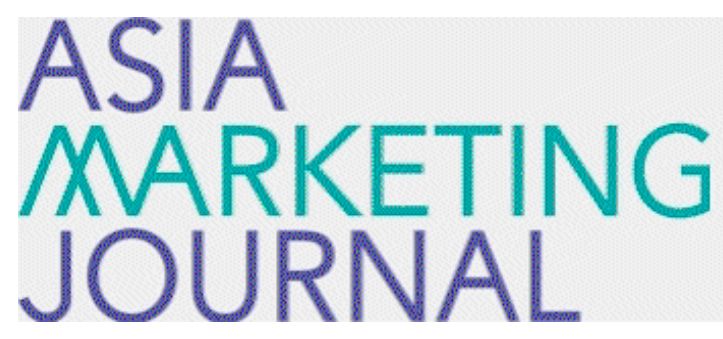

ASIA MARKETING JOURNAL

Volume 17 | Issue 3

Article 2

10-31-2015

\title{
The Antecedents and Consequences of Effective Brand \\ Positioning
}

Changju Kim

Eunji Seo

Junghwa Hong

Kang

Stephen J. Newell

Follow this and additional works at: https://amj.kma.re.kr/journal

Part of the Marketing Commons

\section{Recommended Citation}

Kim, Changju; Seo, Eunji; Hong, Junghwa; Kang; and Newell, Stephen J. (2015) "The Antecedents and Consequences of Effective Brand Positioning," Asia Marketing Journal: Vol. 17 : Iss. 3 , Article 2. Available at: https://doi.org/10.15830/amj.2015.17.3.33

This Article is brought to you for free and open access by Asia Marketing Journal. It has been accepted for inclusion in Asia Marketing Journal by an authorized editor of Asia Marketing Journal. 


\title{
The Antecedents and Consequences of Effective Brand Positioning
}

\author{
Changju Kim* \\ Eunji Seo** \\ Junghwa Hong*** \\ Sangmin Kang**** \\ Stephen J. Newell ${ }^{* * * * *}$
}

\begin{abstract}
This study investigates which variables most effectively influence the positioning strategy of a brand. In addition, we test the connection between the positioning strategy of the brand and loyalty. Finally, we explore how brand experience effects the relationship between brand position and brand loyalty. To this end, this study employs the street-intercept method to collect data on consumers' perception of home appliances in Japan and conducts structural equation modeling analysis to test our hypotheses. Specifically, we find that assessments of product, service, and image have a significant impact on a brand's position which, in turn, drives brand loyalty. In addition, brand experience seems to moderate the relationship between service and brand positioning effectiveness. We also find that price promotions negatively affect brand loyalty. The research provides a consumer-centered, experiential view of how firms can develop strategies to more effectively position brands and increase loyalty among their customers. These results help both academics and practitioners to better understand how consumers assess a brand's position in the marketplace.
\end{abstract}

Key words: brand positioning effectiveness, service, brand loyalty, differentiation

\footnotetext{
* Associate Professor, Ritsumeikan University, Japan (cjkim777@fc.ritsumei.ac.jp), First Author

** Assistant Professor, Fukuyama-heisei University, Japan (eunji0109@heisei-u.ac.jp), Co-author

*** Associate Professor, Saga University, Japan (hongsz@cc.saga-u.ac.jp), Co-author

**** Doctoral Student, Ritsumeikan University, Japan (gr002085@ed.ritsumei.ac.jp), Co-author

***** Professor, Western Michigan University, United States (steve.newell@wmich.edu), Corresponding Author
} 


\section{Introduction}

Researchers have long established the importance of creating competitive advantages through brand loyalty (Aaker 1996; Keller 1998; Kapferer 2008). Finding ways to develop stronger brand loyalty has become even more essential as firms develop strategies to remain profitable in the current competitive global marketplace. One of the ways in which to develop loyalty is through effective positioning of the brand. Positioning strategy has been investigated from both strategic and operational viewpoints (Ellson 2004) and has been investigated in the context of firm-consumer relationships (Darling 2001), interfirm transactions (Kalafatis, Tsogas, and Blankson 2000), and inter-firm competition (Porter 1980). Early research on positioning focused on creating differentiation through the traditional marketing mix variables (product, price, place and/ or promotion) (Hooley and Saunders 1993). Many studies have framed positioning from a firm perspective (Fournier 1998; Keller, Sternthal, and Tybout 2002; Kotler and Keller 2007; Ries and Trout 1986). Other studies have suggested that consumer brand experiences play a role in developing perceptions of brand loyalty (Brakus, Schmitt, and Zarantonello 2009; Sheinin 2000; Völckner and Sattler 2006) and have focused on positioning from the standpoint of benefits derived from satisfying the needs and wants of consumers. These benefits can be intangible (feelings or perceptions) or they can be based on tangible features or functions (Park, Jaworski, and Maclnnis 1986). Overall, understanding the specific issues that determine effective consumer brand positioning and help to establish loyalty is extremely valuable to companies (Schiffman and Kanuk 2007).

In response, the objective of this study is to examine antecedents and consequences of effective brand positioning. Specifically, this study first investigates which specific consumer benefits drive effective brand positioning strategy. Second, we test the relationship between positioning strategy and brand loyalty. Next, we examine whether brand experience moderates the relationship between positioning strategy and loyalty. Finally, we discuss the results and present practical implications for marketing managers for their brands.

\section{Conceptual background}

Developing a positioning strategy consists of creating an image of company, product or brand to occupy a distinctive place in the minds of the target market (Darling 2001; Ellson 2004; Fuchs and Diamantopoulos 2010; Kalafatis, Tsogas, and Blankson 2000). This strategy is often discussed in two specific formats: strategic positioning and brand (operational) positioning (Ellson 2004). Strategic positioning focuses on 
firms' competitive stance in comparison to ri- $^{-}$ valries in the industry, while brand positioning focuses on how a product distinguishes itself against other similar competitive brands. It is important for firms first, to establish the position of their company in the marketplace and then second, to develop appropriate brand strategies in order to create a consistent positioning message that is consistent for all their products and services.

Consumers assess value based on the brand positioning perceptions in the market versus other alternative substitutes (Aaker and Shansby 1982). Brand positioning is a well-established strategic tool which enables firms to develop a unique impression of their products and service in the consumer's minds (Keller 1998). Specifically, brand positioning theory is the ability to differentiate their products from the competition (Ries and Trout 1986). Fuchs and Diamantopoulos (2010) defined positioning effectiveness as the extent to which consumers perceive a brand as favorable, differentiated and credible. Keller, Sternthal, and Tybout (2002) also suggest that in order to develop an effective brand positioning strategy, a company needs to properly consider point of parity as well as the point of differentiation from the products and service of the competition. Park, Jaworski, and Maclnnis (1986) introduced a brand concept management model in which they divide the process into three stages: 1) introduction, 2) concept elaboration, and 3) concept fortification. This struc- ture provides specific actions that managers can take at each stage of the process and insights into the significance of brand image management from a long-term perspective.

Given the number of products that compete in the increasingly competitive global market, is it possible for companies to find a unique and effective place to position their products? To create effective brand positioning strategies, companies need to accomplish two objectives. First, a firm needs to establish benefits and advantages that are important to their target market (Aaker 1996). Next, a company needs to clearly communicate the benefits to these consumers (Krishnan 1996). When firms effectively execute these actions, perceived value is created, loyalty is established and ultimately, brand equity increases.

Recently, Fuchs and Diamantopoulos (2010) investigated whether the type of strategy affects the positioning effectiveness of a brand. Specifically, they empirically compared four different positioning strategies: feature positioning, direct (function) benefit positioning, indirect (experiential/symbolic) benefit positioning, and user positioning. The study measured positioning effectiveness as an outcome of consumer's perception of favorability, differentiation and credibility of the brand. The results indicate that both benefit-based (advantages) positioning and surrogate-based (consumer associations) positioning are more effective than featurebased positioning in creating effective positioning 
strategies. However, the study fails to determine which specific benefits drive effective positioning strategies. In response, Kotler and Keller (2007) propose five distinct benefits that affect differentiation. These are product, service, staff, channel, and image.

Though much research has been undertaken to understand how to develop positioning strategy through mass media advertising, little research has been done to determine if consumers perceptions of a brand's position is affected by activities within the store where the product is purchased. Pan and Zinkhan (2006) argue that consumers are highly influenced by retail variables such as store environment, customer service, staff, and price promotions. In Japanese supermarkets, it is reported that 74\% of consumers make brand choices in a store whereas only $26 \%$ of consumers decide which brand they get outside of a store (Kim 2012). Consequently, it would be important for companies to better understand the role that variables within the retail setting play in affecting positioning effectiveness. Kotler and Keller (2007) suggest that there are five factors that are important in differentiating product offerings and contribute to positioning effectiveness. They are product, service, staff, channel, and image. Interestingly, the outcomes of these factors are significantly affected by consumers' past experiences with the brand (Brakus, Schmitt, and Zarantonello 2009).

\section{Hypotheses and Research Model}

\subsection{The Effect of Differentiation on Positioning Effectiveness}

Products are often differentiated by specific tangible features and benefits that are easily explained or demonstrated such as ease of use, quality perceptions or general reliability (Barroso and Giarratana 2013; Storey and Easingwood 1999). When consumers need to satisfy their needs, they choose the best solution among several substitutes. Common benefits that drive consumer product choice vary by product category (Gwin and Gwin 2003). For example, in case of home appliances, ease of use and reliability would be important benefits to most consumers who are in the market for products within this category (Koshkaki 2014). Overall, evaluations of a product's overall quality, ease of use and reliability will impact perceptions of the positioning of a brand. Hence, we posit:

\section{H 1a: Evaluations of a product significantly influence brand positioning effectiveness.}

Service is a typical intangible benefit of many products. As intangible benefits are unseen, it is often difficult to identify and evaluate these factors (Vargo and Lusch 2008). However, considering the fact that intangible benefits are 
hard to imitate, differentiating a product in terms of its service components may be an important way to gain competitive leverage. Such service facilitates the use of the core product by improving and adding additional value (Frow, Ngo, and Payne 2014). For example, when consumers purchase an air conditioner, quick, delivery and competent installation services will enhance the value of core product. Also services, like a well-established warranty and repair policy can reduce perceived risk and help to persuade consumers to purchase (Goyal 2008). Service plays a significant role in developing a distinctive brand positioning especially when most tangible product features are common among all competitive brands. Overall, favorable service promotes brand positioning effectiveness. Accordingly, we predict:

\section{H 1b: Evaluations of product-related services significantly influence brand position- ing effectiveness.}

The attitude and expertise of the staff, of both the store and the company manufacturing the product, may have a direct effect on brand choice (Grewal, Levy, and Kumar 2009; Mitchell 2001). The staff play a key role for purchase decisions in store, particularly for products that are complex (Anderson and Claxton 1982). In these situations, specific product benefits can be presented and questions answered by skillful and experienced staff. Staff in retail set- tings that sell shopping goods are expected to be well trained in merchandising, sales assistance, and product knowledge (Amato and Amato 2009). Therefore, the staff's ability provides excellent customer support will help to establish positive brand positioning. In light of this reasoning, we suppose:

\section{H1c: Evaluations of staff support significantly influence brand positioning effectiveness.}

Consumers expect retailers to have a number of convenient locations and product choices when shopping (Levy and Weitz 2004). Most retailers try to create an optimal channel for their customers (Coughlan et al. 2006). The channel can be differentiated in both coverage and expertise (Kotler and Keller 2007). For the purposes of this paper, coverage indicates the number and location of retail stores in which consumers can purchase the specific brand. Expertise refers to the number of product choices within a category that the store offers. Superior channel coverage and expertise enables firms to enhance image and increase satisfaction of their customers (Aghekyan-Simonian et al. 2012; SchrammKlein et al. 2011). Overall, satisfaction gained from the well-managed channel will enhance perceptions of brand positioning effectiveness. Consequently, we propose:

H1d: Evaluations of channel significantly
influence brand positioning effectiveness. 
Based on previous studies, developing a positive brand image is vitally important to overall brand positioning (Liljander, Polsa, and van Riel 2009; Park, Jaworski, and Maclnnis 1986). Image is formed by past direct or indirect experiences of the product (Semeijn, van Riel, and Ambrosini 2004). Perceptions of image are often developed through experiential, symbolic, and emotional interactions with the product (Aghekyan-Simonian et al. 2012; Fuchs and Diamantopoulos 2010). Positive images can be initiated or reinforced by advertising and other promotions that convey tangible and intangible benefits of the product. Overall, research suggests that a positive image of a product and/or brand is important to enhancing its positioning effectiveness (Fuchs and Diamantopoulos 2010). Thus, we propose:

H1e: Evaluations of the image of a brand significantly influence brand positioning effectiveness.

\subsection{The Effect of Positioning Effectiveness on Brand Loyalty}

In practice, firms often manipulate their brand positioning through differentiation. Effectively implementing such strategy can lead to creating a positive and distinct place among competitors in the marketplace (Wei 2008). An effective positioning strategy enables firms to $\mathrm{cre}^{-}$ ate positive brand associations, drive purchase, and eventually create brand loyalty (Jung 2015; Schiffman and Kanuk 2007). Brands that are effectively positioned in the marketplace drive enhanced perceptions of corporate credibility and improved evaluations of even quite dissimilar brand extensions (Harris and de Chernatony 2001; Keller and Lehmann 2006; Park 2015). Consumers who are loyal to a brand purchase the brand more frequently and are less likely to switch to other competitors (Ailawadi, Neslin, and Gedenk 2001; Pan and Zinkhan 2006). Overall, effective brand positioning leads to increased consumer loyalty. Consequently, we propose:

H2: Effective brand positioning significantly and positively affects brand loyalty.

\subsection{The Moderating Effect of Consumer Experience}

Consumer experiences occur when individuals search for information, buy a product, receive service, and ultimately consume the product and services (Brakus, Schmitt, and Zarantonello 2009). Past research has been undertaken to determine how to strategically manage consumers' interaction with the company, product, and service throughout the entire purchasing process (Koshkaki 2014; Puccinelli et al. 2009; Schmitt 2003). Overall, this research suggests that these interactions play a key role in developing the feelings the customer has for the brand. Positive brand experience has been shown 
to lead to more pleasurable sensory memory of the product (Osajima, Sternquist, and Manjeshwar 2010) and an increase in product satisfaction and loyalty (Iglesias, Singh, and Batista-Foguet 2011). Overall, positive experiences with product, service, staff, channel, and image create more favorable brand experience and effectiveness of brand positioning as a consequence of consumers having more favorable brand memories. Therefore, we posit:

H3: The positive relationship between H3a) product, H3b) service, H3c) staff, H3d) channel, H3e) image and brand positioning effectiveness is greater for those who consider brand experience relatively important than for those who consider brand experience relatively less important in situation where they choose a brand.

\subsection{Control Variables}

In addition, this study examines price promo- tion as a control variable. Consumers' price perceptions are present and salient in almost all purchase situations (Alford and Biswas 2002; Lichtenstein, Ridgway, and Netemeyer 1993; Jiang and Rosenbloom 2005). Price often influence a brand positioning strategy and may ultimately affect brand loyalty (Allender and Richards 2012). Studies have suggested that in general, consumers who are more price conscious are less loyal to the brand (Manzur et al. 2011). Consequently, price-focused promotions will negatively affect both brand positioning effectiveness and brand loyalty (see Figure 1).

\section{Methodology}

\subsection{Research Context and Data Collection}

To confirm the proposed research model Figure 1 , we surveyed consumers' perception of home appliances in Japan. The street-intercept method

〈Figure 1〉 Proposed Research Model

\section{Differentiation}

\begin{tabular}{|l|}
\hline - Product \\
- Service \\
- Staff \\
- Channel \\
- Image \\
\hline
\end{tabular}

Positioning

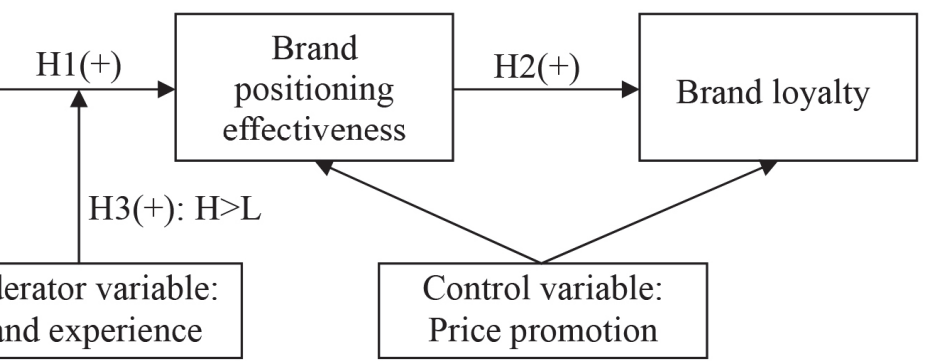


was employed to produce more representative distributions of age, gender, and income (Miller et al. 1997). We collected 367 responses in the area of Kansai, Japan. The brief description of sample profile is shown in Table 1.

In the context of Japanese market, home appliance manufacturers have struggled to find feasible solutions with regards to managing brand positioning strategy because their brand power has been steadily weakened in two specific aspects: consumer demographics and power shift to retailers from manufacturers.

Consumer perceptions and attitudes toward a brand seem to vary based on age and generation. For example, those individuals considered the "new breed" (i.e., people born in the first half of the 1960s) are sensitive to prestige and are potentially more brand loyal, whereas secondary baby-boomers (a temporary increase in the birthrate in 1975-79) are more value conscious and less brand loyal (Osajima, Sternquist, and Manjeshwar 2010). To better understand these differences, we need to address the historical trend of the Japanese economy. The financial situation in Japan has been weak since the collapse of economic bubble in 1991. The new breeds were born into an economy that provided for many an affluent life with much personal disposal income. Many of the second baby-boomers, on the other hand, have lived under more austerity and limited financial opportunities. These different environments have led the younger generation to emphasize price in driving their product buying decisions.

A power shift from manufactures to retailers has been occurred in many western countries (Amato and Amato 2009). This has occurred, in part, because of the large influx of new products by an increasing number of manufacturers. Consequently, retailers have a significant number of product and brand choices to fill limited shelf and store space. This creates competition among manufacturers and retailers can thus, are able to negotiate favorable terms and con-

〈Table 1〉 The Summary of Sample Profile

\begin{tabular}{|c|c|c|c|c|}
\hline $\mathrm{Age}^{\mathrm{a}}$ & $\begin{array}{c}\text { Under } 39 \\
175(48.6 \%)\end{array}$ & $\begin{array}{r}\text { Ov } \\
186\end{array}$ & & $\begin{array}{c}\text { Missing data } \\
7(1.9 \%)\end{array}$ \\
\hline Gender & $\begin{array}{c}\text { Male } \\
186(51.5 \%)\end{array}$ & $\begin{array}{r}\mathrm{Fe} \\
174\end{array}$ & & $\begin{array}{c}\text { Missing data } \\
7(1.9 \%)\end{array}$ \\
\hline $\begin{array}{l}\text { Annual } \\
\text { income }^{b}\end{array}$ & $\begin{array}{c}\text { Under } \$ 51,000^{c} \\
123(36.8 \%) \\
\end{array}$ & $\begin{array}{c}\$ 51,000 \sim \$ 89,000 \\
151(45.2 \%)\end{array}$ & $\begin{array}{c}\text { Over } \$ 89,000 \\
60(16.4 \%)\end{array}$ & $\begin{array}{c}\text { Missing data } \\
33(9.0 \%) \\
\end{array}$ \\
\hline Frequency $^{\mathrm{d}}$ & $\begin{array}{l}\text { Under once } \\
53(14.4 \%)\end{array}$ & $\begin{array}{c}\text { 1 2 times } \\
222(60.5 \%)\end{array}$ & $\begin{array}{c}\text { Over } 3 \text { times } \\
86(23.4 \%)\end{array}$ & $\begin{array}{c}\text { Missing data } \\
6(1.6 \%)\end{array}$ \\
\hline
\end{tabular}


ditions of trade. This environment increases the need for greater emphasis on sales promotions (both trade- and consumer-oriented) versus traditional advertising (Kim, Xu, and Hyde 2011).

\subsection{Measurements}

The measures used in quantifying these constructs are displayed in Table 2. With the ex-

〈Table 2〉 Constructs and Measurement Assessment

\begin{tabular}{|c|c|c|}
\hline Constructs and scale items & Estimate $^{a}$ & $\mathrm{CR}$ \\
\hline $\begin{array}{l}\text { Product } \\
\text { Easy to use } \\
\text { high quality } \\
\text { Reliability for the intended functions }\end{array}$ & $\begin{array}{l}.64 \\
.85 \\
.54\end{array}$ & .79 \\
\hline $\begin{array}{l}\text { Service } \\
\text { Relevant warranty and repair policy } \\
\text { Good delivery service after purchasing } \\
\text { Good installation service }\end{array}$ & $\begin{array}{l}.58 \\
.81 \\
.86\end{array}$ & .77 \\
\hline $\begin{array}{l}\text { Staff } \\
\text { Excellent knowledge on product } \\
\text { Polite customer service } \\
\text { Speedy customer support for inquiry } \\
\text { Excellent customer consulting }\end{array}$ & $\begin{array}{l}.73 \\
.88 \\
.90 \\
.78\end{array}$ & .90 \\
\hline $\begin{array}{l}\text { Channel } \\
\text { Store's expertise in dealing with home appliances } \\
\text { Store's broad and depth assortment } \\
\text { Number of stores which you can buy specific brand }\end{array}$ & $\begin{array}{l}.64 \\
.69 \\
.62\end{array}$ & .69 \\
\hline $\begin{array}{l}\text { Image } \\
\text { Product colors } \\
\text { Brand slogans } \\
\text { Image associated with atmosphere } \\
\text { Image associated with media }\end{array}$ & $\begin{array}{l}.50 \\
.64 \\
.85 \\
.73\end{array}$ & .77 \\
\hline $\begin{array}{l}\text { Brand positioning effectiveness } \\
\text { I understand the value offered by the brand } \\
\text { I can easily tell the differences among brands } \\
\text { The brand's benefits are well-positioned in the minds } \\
\text { I know the differences in the brand benefits when comparing competing brands }\end{array}$ & $\begin{array}{l}.69 \\
.81 \\
.84 \\
.73\end{array}$ & .86 \\
\hline $\begin{array}{l}\text { Brand loyalty } \\
\text { I always try to buy this brand as far as possible } \\
\text { This brand is the only one I want to use } \\
\text { I'd try to use this brand despite of much efforts to find }\end{array}$ & $\begin{array}{l}.78 \\
.86 \\
.89\end{array}$ & .86 \\
\hline $\begin{array}{l}\text { Price promotion } \\
\text { Low price } \\
\text { Frequent special sales } \\
\text { Additional service available for free }\end{array}$ & $\begin{array}{l}.61 \\
.80 \\
.77\end{array}$ & .74 \\
\hline $\begin{array}{l}\text { Brand experience } \\
\text { I consider past brand experience as important when making buying decisions }\end{array}$ & $\mathrm{n} / \mathrm{a}$ & $\mathrm{n} / \mathrm{a}$ \\
\hline
\end{tabular}

Note: ${ }^{a}$ Standardized coefficients 
ception of brand experience, other measures were reflective and had multiple items. These were defined as follows. For the five constructs of differentiation, we measured each contrast based on the Kotler and Keller (2007) guidelines. To achieve consistency, we modified them to better assess the construct of interest. The constructs of product, service, and channel each contained three-items, while staff and image were four-item measures. We asked respondents to what extent each item influenced their decision to buy using a five-point scale (anchored by " $1=$ very weak" and " $5=$ very strong"). We also used a four-item measure for brand positioning effectiveness (Fuchs and Diamantopoulos 2010; Kalafatis, Tsogas, and Blankson 2000). We measured brand loyalty with a three-item scale (Osajima, Sternquist, and Manjeshwar 2010). As a control variable, price promotion was measured using a three-item scale based on research by Allender and Richards (2012). Finally, as a moderating variable, we measured brand experience with a single-item scale based (Brakus, Schmitt, and Zarantonello 2009). For loyalty, brand positioning effectiveness, price promotion and brand experience, we utilized a five-point scales anchored by "1 = completely disagree" and " 5 = totally agree".

\subsection{Common Method Bias}

Because the data was collected with a single survey instrument, we tested for common method bias using Harman's single-factor test (Podsakoff et al. 2003). It appears that the fit of the singlefactor model is significantly worse than that of the full-factor model $\left(\triangle \chi^{2}(54)=2653.57\right.$, $\mathrm{p}<$.001). Additionally, exploratory factor analysis using an unrotated component matrix revealed that the items did not load on a single construct. The first factor, staff, explains only $11.31 \%$ of the total variance of $68.13 \%$. Thus, common method bias is not a problem for our data.

\section{Analysis and Results}

\subsection{Construct Validity}

This article examined the proposed research model in Figure 1 using structural equation modelling procedures. We confirmed construct validity through confirmatory factor analysis (CFA). The measurement model exhibits a satisfactory fit to the data $\left(\chi^{2}(296)=549.17\right.$, $\mathrm{p}<.05$, GFI $=.90$, RMSEA $=.05$, CFI $=$ .94 , IFI $=.94)$. We assessed convergent validity with construct reliability (CR). As indicated in Table 2, CR values range from .74 to .90, which exceeds the threshold of 7 (Hair et al. 2010). The standardized coefficients for all items are above .5 and p-value for each is significant at a significance level of .01. We then checked for discriminant validity by com- 
paring the fit of the one-construct model (correlation between factors constrained to unity) with the original two-construct model (correlation between factors free) (Bagozzi and Yi 1988). The results revealed that the fit of the any two-construct model was significantly different from that of the one-construct model. For example, looking at the result of service and staff indicating the highest correlation in Table 3 , the fit of the original two-construct model is significantly different $\left(\triangle \chi^{2}(1)=88.96, \mathrm{p}<\right.$ .001).

\subsection{Results of Hypothesis Testing}

The results of hypothesis testing indicate evidence of satisfactory fit for the structural model $\left(\chi^{2}(300)=552.38, \mathrm{p}<.05\right.$, GFI $=$ .90$, RMSEA $=.05$, CFI $=.94$, IFI $=.94)$. We examined the main effects of hypothesized direct effects. As summarized in Table 4, product $(\gamma=.19, \mathrm{p}<.01)$, service $(\gamma=.17, \mathrm{p}<.05)$, and image $(\gamma=.27, \mathrm{p}<.001)$ are positively associated with brand positioning effectiveness. These findings are consistent with our prediction, and consequently H1a, H1b, and H1e are accepted. Staff and channel are not significantly linked to brand positioning effectiveness. Thus, we reject $H 1 c$ and $H 1 d$. The results though suggest that the impact of brand positioning effectiveness on brand loyalty is significant and positive $(\beta=.47, p<.001)$, in support of $H 2$. As for control variables, price promotion is negatively associated with brand loyalty as predicted, but is not significantly linked to brand positioning effectiveness.

Next, we tested the moderating roles of brand experience by applying multi-group analysis. To this end, the data were divided into two groups (high and low) of brand experience on the basis of mean value (3.60). High group ( $n$ $=222$ ) above the mean value refers to con-

〈Table 3〉 Descriptive Statistics and Correlation Matrix

\begin{tabular}{lcccccccccc}
\hline & Mean & SD & X1 & X2 & X3 & X4 & X5 & X6 & X7 & X8 \\
\hline X1 Product & 4.35 & .66 & & & & & & & & \\
X2 Service & 3.60 & .93 & $.22^{\mathrm{b}}$ & & & & & & & \\
X3 Staff & 3.89 & .85 & $.24^{\mathrm{b}}$ & $.57^{\mathrm{b}}$ & & & & & & \\
X4 Channel & 3.48 & .78 & $.18^{\mathrm{b}}$ & $.32^{\mathrm{b}}$ & $.40^{\mathrm{b}}$ & & & & & \\
X5 Image & 3.02 & .80 & .05 & $.12^{\mathrm{b}}$ & $.11^{\mathrm{b}}$ & $.28^{\mathrm{b}}$ & & & & \\
X6 BPE & 3.10 & .79 & $.17^{\mathrm{b}}$ & $.13^{\mathrm{b}}$ & .04 & $.14^{\mathrm{b}}$ & $.23^{\mathrm{b}}$ & & & \\
X7 Brand loyalty & 2.55 & 1.01 & $.12^{\mathrm{b}}$ & $.15^{\mathrm{b}}$ & $.14^{\mathrm{b}}$ & $.14^{\mathrm{b}}$ & $.22^{\mathrm{b}}$ & $.39^{\mathrm{b}}$ & & \\
X8 Price promotion & 3.43 & .91 & $.11^{\mathrm{b}}$ & $.20^{\mathrm{b}}$ & $.15^{\mathrm{b}}$ & $.13^{\mathrm{b}}$ & .07 & .06 & $-.12^{\mathrm{b}}$ & \\
X9 Brand experience & 3.60 & .98 & $.25^{\mathrm{b}}$ & $.14^{\mathrm{b}}$ & $.12^{\mathrm{b}}$ & $.19^{\mathrm{b}}$ & $.43^{\mathrm{b}}$ & $.20^{\mathrm{b}}$ & $.21^{\mathrm{b}}$ & .04 \\
\hline
\end{tabular}

Notes: ${ }^{\mathrm{a}} \mathrm{BPE}=$ Brand positioning effectiveness: ${ }^{\mathrm{b}} p<.05$ 
〈TABLE 4〉 Path Analysis Results for Main Effects

\begin{tabular}{lcc}
\hline \multicolumn{1}{c}{ Hypothesized path } & Direction & Estimate $^{\mathrm{a}}$ \\
\hline Main effects & + & $.19^{* *}$ \\
H1a. Product $\rightarrow$ Brand positioning effectiveness & + & $.17^{*}$ \\
H1b. Service $\rightarrow$ Brand positioning effectiveness & + & -.13 \\
H1c. Staff $\rightarrow$ Brand positioning effectiveness & + & .01 \\
H1d. Channel $\rightarrow$ Brand positioning effectiveness & + & $.27^{* * *}$ \\
H1e. Image $\rightarrow$ Brand positioning effectiveness & + & $.47^{* * *}$ \\
H2. Brand positioning effectiveness $\rightarrow$ Brand loyalty & & \\
Control variables & - & -.01 \\
Price promotion $\rightarrow$ Brand positioning effectiveness & - & $-.13^{*}$ \\
Price promotion $\rightarrow$ Brand loyalty & & \\
\hline
\end{tabular}

Notes: ${ }^{a}$ Standardized coefficients: ${ }^{*} p<.05 ;{ }^{* *} p<.01 ;{ }^{* * *} p<.001$

sumers who consider brand experience relatively important compared with low group $(\mathrm{n}=145)$ below the mean value when buying appliances. We then performed a series of $\chi^{2}$ difference tests. The results presented in Table 5 suggest that the path from differentiation to brand po- $^{-}$ sitioning effectiveness differ somewhat across the type of brand experience. The $\chi^{2}$ difference test between the constrained and freely estimated models reveals significant different for the path of service $\rightarrow$ brand positioning effectiveness $\left(\triangle \chi^{2}(1)=5.02, \mathrm{p}<.05\right)$. Consequently,
$H 3 b$ is supported. The other four paths are not significant and, accordingly, H3a, H3c, H3d, and $H 3 e$ are not supported.

\section{Discussion and implications}

\subsection{Theoretical Implications}

This study investigated how firms' efforts into differentiation strategy affect the effectiveness

〈Table 5〉 Results for Moderating Effects of Brand Experience

\begin{tabular}{llccc}
\hline \multicolumn{1}{c}{ Hypothesized path } & \multicolumn{2}{c}{$\begin{array}{c}\text { Standardized coefficients } \\
\text { High group }\end{array}$} & $\begin{array}{c}\text { Low } \text { group } \\
\text { difference test }^{\mathrm{b}}\end{array}$ & Result $^{\mathrm{a}}$ \\
\hline H3a. Product $\rightarrow \mathrm{BPE}^{\mathrm{a}}$ & $.16^{\dagger}$ & .14 & $\mathrm{df}(1)=.02$ & Rejected \\
H3b. Service $\rightarrow \mathrm{BPE}$ & $.32^{* *}$ & -.05 & $\mathrm{df}(1)=5.02$ & Accepted \\
H3c. Staff $\rightarrow \mathrm{BPE}$ & -.16 & -.16 & $\mathrm{df}(1)=.01$ & Rejected \\
H3d. Channel $\rightarrow \mathrm{BPE}$ & -.01 & .18 & $\mathrm{df}(1)=.61$ & Rejected \\
H3e. Image $\rightarrow \mathrm{BPE}$ & $.33^{* * *}$ & .11 & $\mathrm{df}(1)=.77$ & Rejected \\
\hline
\end{tabular}

Notes: ${ }^{a}$ Brand positioning effectiveness; ${ }^{\mathrm{b}}$ Values greater than 3.84 are significant at a .5 level $\left(\triangle \chi^{2}(1)=3.84, \mathrm{p}<\right.$ $.05) ;{ }^{\dagger} \mathrm{p}<.10 ;{ }^{* *} p<.01 ; * * * p<.001$ 
of brand positioning and the impact this has on brand loyalty. We confirmed that product, service, and image all have a positive impact on brand positioning effectiveness, which, in turn, significantly affects brand loyalty. Further, we explored the moderating role of brand experience on a company's differentiation activities. Our findings reveal that brand experience does indeed moderate the relationship between service and brand positioning effectiveness and that price promotions negatively impact brand loyalty.

Specifically, the results indicate that product (H1a), service (H1b), and image (H1e) positively influence brand positioning effectiveness, and this effectiveness improves consumers' brand loyalty (H2). Consequently, drawing on the effectiveness perspective on brand positioning theory (Fuchs and Diamantopoulos, 2010), we argue that companies should applying differentiation to develop brand positioning strategies in order to create brand loyalty.

To provide an insight into reasons why, staff and channel do not significantly impact positioning effectiveness as hypothesized, we need to better understand the home appliance market in Japan. As mentioned earlier, the emergence of powerful retailers have taken negotiation leverage away from manufacturers. Under this circumstance, retailers utilize their buying power against manufacturers by handling a broad and deep merchandise assortment. In addition, they often promote a variety of products using significant price concessions to drive sales (Touboulic,
Chicksand, and Walker 2014). In response, manufacturers started to send their own salespeople to the retail stores. Originally, the role of the salesperson in a retail setting was to help the retailers help customers to find products that best fit their needs.

However, in reality, once in the store, many of these manufacturer's representatives focused their energies on promoting only their own company's products and service, sometimes irrespective of consumers' interests. Consequently, when consumers visit appliance retail stores, they may receive biased information and may not be provided information on all of the available product options. In addition, perceptions of customer service may be linked to whether the sales person has a personal stake in the purchased product. Sales reps may also be more apt to provide higher quality service for those products that come from their own companies, and spend less time and energy providing services to the competitor's offerings. For these reasons, staff and channel may not be significantly associated with brand positioning effectiveness.

In addition, we have added to emerging research of brand experience (Brakus, Schmitt, and Zarantonello 2009) as it relates to brand positioning theory. The results suggest that the positive relationship between brand experience and brand positioning effectiveness is greater for those who consider brand experience more important than for those who consider it relatively less important (H3b). Consequently, brand 
experience plays a moderating role between firms' differentiation activities and brand positioning effectiveness.

Another notable result of the research is that service seems to perform a salient function in developing brand positioning effectiveness. In relation to home appliances, we speculate that manufacturers' and their policies regarding warranty and repair policy, delivery, and installation services improves the effectiveness of the brand positioning by adding additional value to the core product (Frow, Ngo, and Payne 2014) while, at the same time, reducing perceived risks to consumers (Goyal 2008). Overall, though the impact of product and image on brand positioning theory has been well established in the extant research, relatively little research has empirically investigated the relationship between service, brand positioning, and brand experience. The results from this study confirm that service, as well as product and image, positively affect brand positioning effectiveness and that perceptions of service becomes the main criterion when consumers are highly conscious of past brand experiences.

\subsection{Practical Implications}

On the basis of the findings, we suggest three practical implications for developing and managing effective brand positioning. First, manufacturers should pay more attentions to service. The results suggest that service is more influ- ential on brand positioning effectiveness for consumers who consider past brand experiences as important in buying decision-making process. Thus, service has to become a much more integral part of brand positioning strategy for companies. Specifically, companies should develop promotional campaigns that revolving around service. For example, companies could offer free service agreements for certain high-priced products or improve the quality of the services that are provided and emphasize this fact in their advertising and promotions. These efforts, when done correctly, help to drive consumer perceptions of quality and value at a relatively low cost to the manufacturer and retailer.

Consumers who buy appliances care about speedy delivery and competent installation of the product. It should be noted that delivery and installation have become essential for many products in the Japanese market which is characterized by an aging society. Approximately 26\% in Japanese population are over 65 years old (12.5\% over 75 years old) in 2014 where aging population over 65 years old were only 12.1\% in 1990. The individuals tend to need help all aspects of the decision-making process from point-of-purchase to delivery and installation. Thus, having a helpful staff to competently answer questions about product choices as well as hiring capable technicians to deliver and install the products, may present possible avenues for developing a differential positioning strategy.

It should be noted that manufacturers pursu- 
ing and managing brand loyalty should be cautious when implementing price-focused promotional strategies. Though price is a key element which helps to facilitate purchase decisions, the results of study suggest a significant and negative impact of price promotion on brand loyalty. Instead of a employing a short-term price reduction strategy to increase sales, manufacturers should turn their attention to less price-focused differentiation of their product. Non-price, positioning-related benefits such as developing a higher quality product or providing more competent service, may be a better way for companies to establish effective positioning for their brands and would, ultimately contribute to stronger brand loyalty.

\subsection{Limitations and Future Research}

The current research is subject to several limitations. First, we narrowed our product investigation to include only home appliances. Consumer's purchase decisions are driven by evaluations of benefits unique to that product. For most consumer goods, issues such as installation, warranty, delivery and repair would not be applicable to their purchase decision. Thus, future research needs to broaden the scope of the products investigated in order to test the broader applicability of the model. In addition, when examining brand management, future studies need to incorporate the dynamics of the relationship between manufacturers and retailers. Contrary to past research, we found no impact of channel and staff on brand positioning effectiveness. Consequently, future $\mathrm{re}^{-}$ searchers need to re-examine these results to confirm their validity.

〈Received October 6. 2015〉

$\langle$ Revised October 27. 2015〉

〈Accepted October 27. 2015〉

\section{References}

Aaker, David A (1996), Building Strong Brands. New York: The Free Press.

Aaker, David A. and J. Gary Shansby (1982), "Positioning Your Product," Business Horizons, 25(3), 56-62.

Aghekyan-Simonian, Marine, Sandra Forsythe, Wi Suk Kwon, and Veena Chattaraman (2012), “The Role of Product Brand Image and Online Store Image on Perceived Risks and Online Purchase Intentions for Apparel," Journal of Retailing and Consumer Services, 19(3), 325-331.

Ailawadi, Kusum L., Scott A. Neslin, and Karen Gedenk (2001), "Pursuing the Value-Conscious Consumer: Store Brands Versus National Brand Promotions," Journal of Marketing, 65(1), 71-89.

Alford, Bruce L. and Abhijit Biswas (2002), "The Effects of Discount Level, Price Consciousness and Sale Proneness on Consumers' 
Price Perception and Behavioral Intention," Journal of Business research, 55(9), 775783.

Allender, William and Timothy J. Richards (2012), "Brand Loyalty and Price Promotion Strategies: An Empirical Analysis," Journal of Retailing, 88(3), 323-342.

Amato, Louis H. and Christie H. Amato (2009), "Changing Retail Power and Performance in Distribution Channels," International Journal of Retail \& Distribution Management, 37 (12), 1057-1076.

Anderson, C. Dennis and John D. Claxton (1982), "Barriers to Consumer Choice of Energy Efficient Products," Journal of Consumer Research, 9(2), 163-170.

Bagozzi, Richard P. and Youjae Yi (1988), "On the Evaluation of Structural Equation Models," Journal of the Academy of Marketing Science, 16(1), 74-94.

Barroso, Alicia and Marco S. Giarratana (2013), "Product Proliferation Strategies and Firm Performance: The Moderating Role of Product Space Complexity," Strategic management Journal, 34(12), 1435-1452.

Brakus, J. Joško, Bernd H. Schmitt, and Lia Zarantonello (2009), "Brand Experience: What is It? How is It Measured? Does It Affect Loyalty?," Journal of Marketing, 73 (3), 52-68.

Coughlan, Anne T., Erin Anderson, Louis W. Stern, and Adel I. El-Ansary (2006), Marketing Channels, 7th ed. Upper Saddle River,
New Jersey: Pearson Education, Inc. Darling, John R. (2001), "Successful Competitive Positioning: The Key for Entry into the European Consumer Market," European Business Review, 13(4), 209-221.

Ellson, Tony (2004), Culture and Positioning as Determinants of Strategy: Personality and the Business Organization. Basingstoke and New York: Palgrave Macmillan.

Fournier, Susan (1998), "Consumer and Their Brands: Developing Relationship Theory in Consumer Research," Journal of Consumer Research, 24(4), 343-373.

Frow, Pennie, Liem Viet Ngo, and Adrian Payne (2014), "Diagnosing the Supplementary Services Model: Empirical Validation, Advancement and Implementation," Journal of Marketing Management, 30(1/2), 138-171. Fuchs, Christoph and Adamantios Diamantopoulos (2010), "Evaluating the Effectiveness of Brand-Positioning Strategies from a Consumer Perspective," European Journal of Marketing, 44(11/12), 1763-1786.

Goyal, Anita (2008), "Managing Perceived Risk for Credit Card Purchase through Supplementary Services," Journal of Financial Services Marketing, 12(4), 331-345.

Grewal, Dhruv, Michael Levy, and V. Kumar (2009), "Customer Experience Management in Retailing: An Organizing Framework," Journal of Retailing, 85(1), 1-14.

Gwin, Carol F. and Carl R. Gwin (2003), "Product Attributes Model: A Tool for Evaluating 
Brand Positioning," Journal of Marketing Theory and Practice, 11(2), 30-42.

Hair Jr, Joseph F., William C. Black, Barry J. Babin, and Rolph E. Anderson (2010), Multivariate Data Analysis: A Global Perspective, 7th ed. New Jersey: Pearson Education, Inc.

Harris, Fiona and Leslie de Chernatony (2001), "Corporate Branding and Corporate Brand Performance," European Journal of Marketing, 35(3/4), 441-456.

Hooley, Graham J. and John A. Saunders (1993), Competitive Positioning: The Key to Market Success. New York: Prentice Hall.

Iglesias, Oriol, Jatinder J. Singh, and Joan M. Batista-Foguet (2011), "The Role of Brand Experience and Affective Commitment in Determining Brand Loyalty," Journal of Brand Management, 18(8), 570-582.

Jiang, Pingjun and Bert Rosenbloom (2005), "Customer Intention to Return Online: Price Perception, Attribute-Level Performance, and Satisfaction Unfolding Over Time," European Journal of Marketing, 39(1/2), 150-174.

Jung, Sang Uk (2015), "Can Brand Equity Explain Excess Behavioral Loyalty?," Asia Marketing Journal, 17(1), 55-67.

Kalafatis, Stavros P., Markos H. Tsogas, and Charles Blankson (2000), "Positioning Strategies in Business Markets," Journal of Business \& Industrial Marketing, 15(6/7), 416-437.
Kapferer, Jean-Noël (2008), The New Strategic Brand Management: Creating and Sustaining Brand Equity Long Term, 4th ed. London: Kogan Page.

Keller, Kevin Lane (1998), Strategic Brand Management: Building, Measuring and Managing Brand Equity. Upper Saddle River, NJ: Prentice-Hall.

Keller, Kevin Lane, Brian Sternthal, and Alice Tybout (2002), “Three Questions You Need to Ask about Your Brand," Harvard Business Review, 80(9), 80-86.

Keller, Kevin Lane and Donald R. Lehmann (2006), "Brands and Branding: Research Findings and Future Priorities," Marketing Science, 25(6), 740-759.

Kim, Changju (2012), "Retail Competitiveness in the Era of Over-Competition (4): In-Store Merchandising Strategy in the Planned Buying of Category [in Japanese]," Kikan Izumiya Soken, 92, 74-77.

Kim, Changju, Yingzi Xu, and Kenneth F. Hyde (2011), "Advertising Versus Sales Promotion: An Examination of the Japanese Food Industry, 1976-2008," Journal of Global Scholars of Marketing Science, 21(4), 193200.

Koshkaki, Emad Rahmanian (2014), “The Role of Product and Brand Emotion in Purchase Behavior, a Study in Iranian Home Appliance Context," Journal of Asia Business Studies, 8(3), 233-248.

Kotler, Philip and Kevin Lane Keller (2007), A 
Framework for Marketing Management, 3rd ed. Upper Saddle River, New Jersey: Pearson Education, Inc.

Krishnan, H. Shanker (1996), "Characteristics of Memory Associations: A Consumer Based Brand Equity Perspective," International Journal of Research in Marketing, 13(4), 389-405.

Levy, Michael and Barton A. Weitz (2004), Retailing Management, 5th ed. Boston: McGraw-Hill/Irwin.

Lichtenstein, Donald R., Nancy M. Ridgway, and Richard G. Netemeyer (1993), "Price Perceptions and Consumer Shopping Behavior: A Field Study," Journal of Marketing Research, 30(2), 234-245.

Liljander, Veronica, Pia Polsa, and Allard van Riel (2009), "Modelling Consumer Responses to an Apparel Store Brand: Store Image as a Risk Reducer," Journal of Retailing and Consumer Services, 16(4), 281-290.

Manzur, Enrique, Sergio Olavarrieta, Pedro Hidalgo, Pablo Farías, and Rodrigo Uribe (2011), "Store Brand and National Brand Promotion Attitudes Antecedents," Journal of Business Research, 64(3), 286-291.

Miller, Kevin W., Lora B. Wilder, Frances A. Stillman, and Diane M. Becker (1997), "The Feasibility of a Street-Intercept Survey Method in an African-American Community," American Journal of Public Health, 87(4), 655-658.

Mitchell, Vincent-Wayne (2001), "Re-conceptualizing
Consumer Store Image Processing Using Perceived Risk," Journal of Business Research, 54(2), 167-172.

Osajima, Kumiko, Brenda Sternquist, and Sonia Manjeshwar (2010), “Japanese Materialism: A Comparison between the New Breed and Second Baby-Boomer Ager-Cohorts," Journal of Asia Business Studies, 4(2), 57-72.

Pan, Yue and George M. Zinkhan (2006), "Determinants of Retail Patronage: A Meta-Analytical Perspective," Journal of Retailing, 82(3), 229-243.

Park, C. Whan, Bernard J. Jaworski, and Deborah J. Maclnnis (1986), "Strategic Brand ConceptImage Management," Journal of Marketing, 50(4), 135-145.

Park, Kiwan (2015), "Effects of Temporal Distance on Brand Extension Evaluation: Applying the Construal-Level Perspective to Brand Extensions," Asia Marketing Journal, 17(1), 97-121.

Podsakoff, Philip M., Scott B. MacKenzie, JeongYeon Lee, and Nathan P. Podsakoff (2003), "Common Method Biases in Behavioral Research: A Critical Review of the Literature and Recommended Remedies," Journal of Applied Psychology, 88(5), 879-903.

Porter, Michael E. (1980), Competitive Strategy: Techniques for Analyzing Industries and Competitors. New York: Free Press.

Puccinelli, Nancy M., Ronald C. Goodstein, Dhruv Grewal, Robert Price, Priya Raghubir, and 
David Stewart (2009), "Customer Experience Management in Retailing: Understanding the Buying Process," Journal of Retailing, 85(1), 15-30.

Ries, Al and Jack Trout (1986), Positioning:

The Battle for Your Mind. New York: McGraw-Hill.

Schiffman, Leon G. and Leslie Lazar Kanuk (2007), Consumer Behavior, 9th ed. Upper Saddle River, NJ: Prentice Hall.

Schmitt, Bernd H. (2003), Customer Experience Management: A Revolutionary Approach to Connecting with Your Customers. New Jersey: John Wiley \& Sons, Inc.

Schramm-Klein, Hanna, Gerhard Wagner, Sascha Steinmann, and Dirk Morschett (2011), "Cross-Channel Integration: Is It Valued by Customers?," International Review of Retail, Distribution and Consumer Research, 21(5), 501-511.

Semeijn, Janjaap, Allard C.R. van Riel, and A. Beatriz Ambrosini (2004), "Consumer Evaluations of Store Brands: Effects of Store and Product Attributes," Journal of Retailing and Consumer Services, 11(4), 247-258.
Sheinin, Daniel A. (2000), "The Effects of Experience with Brand Extensions on Parent Brand Knowledge," Journal of Business Research, 49(1), 47-55.

Storey, Chris and Christopher J. Easingwood (1999), “Types of New Product Performance: Evidence from the Consumer Financial Services Sector," Journal of Business Research, 46(2), 193-203.

Touboulic, Anne, Daniel Chicksand, and Helen Walker (2014), "Managing Imbalanced Supply Chain Relationships for Sustainability: A Power Perspective," Decision Sciences, 45 (4), 577-619.

Vargo, Stephen L. and Robert F. Lusch (2008), "Why 'Service??, Journal of the Academy of Marketing Science, 36(1), 25-38.

Völckner, Franziska and Henrik Sattler (2006), "Drivers of Brand Extension Success," Journal of Marketing, 70(2), 18-34.

Wei, Yujie (2008), "Does Consumer Ethnocentrism Affect Purchase Intentions of Chinese Consumers? Mediating Effect of Brand Sensitivity and Moderating Effect of Product Cues," Journal of Asia Business Studies, 3(1), 54-66. 